\title{
Verbond, geloof en geloofservaring
}

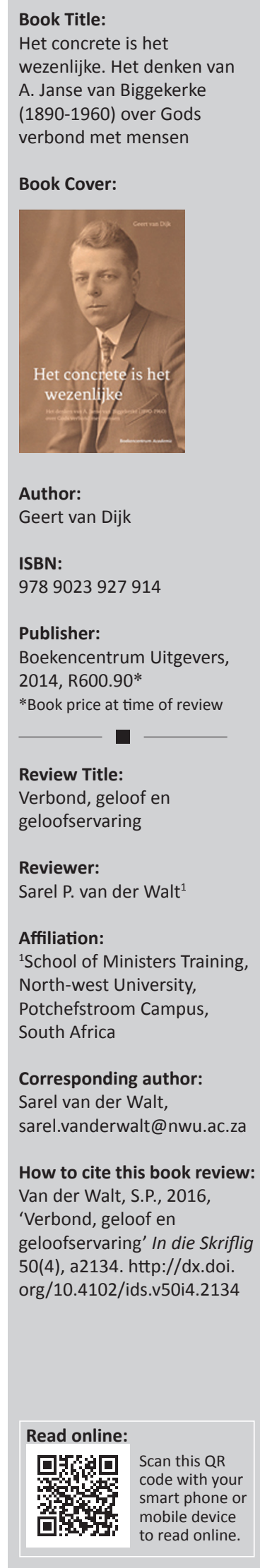

'n Biografie in vele opsigte, is hierdie boek die resultaat van 'n PhD-studie deur Geert van Dijk, predikant van die Nederlands Gereformeerde Kerk in Sliedrecht. Die boek handel oor die leer en lewe van Atheunis Janse, 'n skoolhoof in 'n klein dorpie in die westelike uithoek van Nederland, Biggekerke in Zeeland, wat veral gedurende die dertigerjare van die vorige eeu gepoog het om geloof te bevry van 'bevinding', oftewel persoonlike geloofservaring.

Aan die begin van die boek skets Van Dijk sy eie (kerk-)historiese agtergrond waarin hy uitwys hoedat sy nuuskierigheid oor die onderwerp van die studie/boek ontwikkel het op grond van sy grootwordjare-ervaring (insluitend sy eie belydenisaflegging onder die leiding van ' $n$ skoonseun van Janse) dat sy eie kerk nie veel aandag geskenk het aan geloofsbelewing in die praktyk nie. Sy eie studies aan die Christelik Gereformeerde Kerk se Teologiese Universiteit in Apeldoorn, bring hom in aanraking met ' $n$ ander belewenis van die verbond, een met meer aandag vir geloofservaring. Dit vind hy verrykend. Hy ontdek dat sy ervaring van die verskille in geloofsbelewing gedeeltelik terug te voer is na die figuur van Janse van Biggekerke, en so ontstaan sy interesse in die figuur en die studie.

Het concrete is het wezenlijke strek oor 293 bladsye met talle verduidelikende voetnotas, bylae(s) (wat insluit briefwisseling tussen B. Telder en Janse - tussen wie 'n hegte vriendskap ontwikkel het - asook 'n gemeenskaplike kerklike verklaring oor toe-eiening van die heil), 'n Engelse opsomming van die boek, 'n lys van geraadpleegde werke asook ander bronne (waaronder onderhoude met familielede en ander teoloë), 'n lys van Janse se publikasies van boeke, brosjures en artikels en 'n register van persone. Die boek word afgesluit met 'n curriculum vitae van die outeur.

Die vraagstelling van die studie bring die uitgangspunt van die boek duidelik aan die orde, naamlik dat dit hier gaan oor die aard van Janse se teologiese siening van die verbond (bl. 17). Hieronder word die volgende temas behandel wat Janse as bedreiging van die vaste verbondsbeloftes van God beskou: die mistiese belewingsgodsdiens, die dialektiese teologie, die skolastiek en verset.

Janse was onder andere bekend vir sy stryd teen abstrakte begrippe, veral wanneer dit konkrete werklikhede na die agtergrond verskuif. Dit blyk veral wanneer dit duidelik word hoedat mistisisme die eerste front was waarteen Janse homself opponeer het. Ervaring as norm ten koste van die konkreetheid van die Bybel het klaarblyklik die tendens in Gereformeerde Protestantisme geword en hierteen was Janse in stryd. Die beskrywing hiervan word in hoofstuk 3 uitgedek nadat hoofstuk 2 oor Janse se jeug en opleiding gehandel het.

Hoofstuk 4 handel oor Janse se stryd teen die dialektiese teologie van Karl Barth en veral die klaarblyklike epistemologiese en filosofiese agtergrond van Barth se dialektiese benadering. Janse het geskerm teen 'n onderwaardering van die Skrif en gevolglike onderwaardering van die waarheid. In die besonder het Janse dit teen Barth gehad dat laasgenoemde belangrike temas in die Bybel, spesifiek die verbond en uitverkiesing, anders verklaar as wat dit werklik beteken.

Hoofstuk 5 handel oor die vraagstuk van selfondersoek en die verhouding tussen liggaam en siel. Vir Janse staan die uitdrukking 'de mens is een levende ziel' voorop in sy gedagtevorming waarmee hy 'n dichotomie tussen liggaam en siel afwys. Die wesenlike van die mens lê nie bloot maar net in die siel nie, maar in die mens as geheel. Dienooreenkomstig lê die wesenlike van die verbond nie bloot maar net in wat Janse inwendig in die innerlike gevoel sien afspeel nie, maar is die uiterlike verbondsbelofte wesenlik vir die korrekte verstaan van die verbond. Hierdie siening het daartoe gelei dat Janse gewaak het teen 'n oordrewe klem op die noodsaak van selfondersoek (sonder om selfondersoek per se af te wys), as sou dit die mens in 'n subjektivistiese afwaartse spiraal weg van God se sekere en vaste verbondsbeloftes vasvang. 
In hoofstuk 6 word teruggekeer na die mistisisme wanneer Van Dijk ook oor Janse se stryd teen die skolastiek handel en waarmee alle deure klaarblyklik toeslaan vir 'n kompromie tussen Janse en sy (teologiese) teëstanders. Enigiets wat geneig het tot 'n fusie tussen God en mens was vir Janse gnosties en per definisie nie-Christelik. Hy definieer mistisisme as die mens se strewe na 'n ontmoeting met God en wat nie deur die rede geverifieer kan word nie. Gnostisisme definieer hy as 'n sektariese geneigdheid waarbinne die siel as 'n oorblyfsel van die goddelike en onsienbare wêreld beskou word. Janse benadruk die konkrete taal van die Skrif teenoor die abstrakte taal van die wetenskap.

In hoofstuk 7 word Janse se siening oor openbare verset beskryf. Gedurende die Tweede Wêreldoorlog het Janse homself skerp kritiek op die hals gehaal vanweë sy standpunt dat die Duitse besetter as die wettige owerheid van die dag gehoorsaam moet word. Janse wys alle vorme van verset, gewapend én passief, af en bevind dat 'n mens lojaal moet wees aan die owerheid, selfs wanneer die owerheid nie volgens God se wil handel nie. Met hierdie siening het Janse waarskynlik baie aansien verloor. 'n Ander stryd gedurende hierdie tyd was die vrymaking van 1944 en sieninge rondom die verbond wat in die diskussies en verskille tot 'n groot mate sentraal gestaan het. Volgens Janse was die oorlog die gevolg van verbondsbreuk.

Dit blyk duidelik uit die boek dat Janse 'n besondere liefde vir, en kennis van God se Woord en die Gereformeerde konfessies gehad het. Sy onvermoeide klem op die verbond en die toepassing daarvan vir die lewe, is prysenswaardig en is op 'n meesterlike wyse deur Geert van Dijk in hierdie werk gedokumenteer. Tog het Janse, as intellektueel by uitstek, waarskynlik sodanig op prinsipes en gedagtes gefokus, dat hy die konkrete mens - en daarmee saam die essensie - uit die oog verloor het, aldus 'n opmerking deur die outeur self.

Alhoewel die boek 'n stewige akademiese werk is, word dit op só'n wyse aangebied dat dit leesbaar en ontvanklik vir enigeen sal wees. Die boek sal waarskynlik 'n beperkte gehoor hê vanweë die aard van die inhoud, maar dit bied 'n interessante en uiters leersame inkyk in 'n unieke deel van die kerklike geskiedenis in Nederland, waarby kerke in Suid-Afrika in hulle ekumeniese skakeling met die kerke in Nederland baat kan vind. 